\title{
Microbiological Quality Assessment by PCR and Its Antibiotic Susceptibility in Mangrove Crabs (Ucides cordatus) from Guanabara Bay, Rio de Janeiro, Brazil
}

\author{
M. C. N. Carvalho, ${ }^{1}$ M. M. Jayme, ${ }^{2}$ G. S. Arenazio, ${ }^{3}$ F. V. Araújo, ${ }^{3}$ \\ S. G. F. Leite, ${ }^{4}$ and E. M. Del Aguila ${ }^{1}$ \\ ${ }^{1}$ Instituto de Química, Universidade Federal do Rio de Janeiro, Avenida Athos da Silveira 149, Bloco A, Cidade Universitária, \\ 21949-909 Rio de Janeiro, RJ, Brazil \\ ${ }^{2}$ Faculdade de Ciências Médicas, Universidade do Estado do Rio do Janeiro (UERJ), Avenida Professor Manoel de Abreu 444, \\ $2^{\circ}$ andar, Vila Isabel, 20550-170 Rio de Janeiro, RJ, Brazil \\ ${ }^{3}$ Faculdade de Formação de Professores, Universidade do Estado do Rio de Janeiro (FFP-UERJ), Rua Dr. Francisco Portela 1470, \\ Patronato, 24435-005 São Gonçalo, RJ, Brazil \\ ${ }^{4}$ Escola de Química, Universidade Federal do Rio de Janeiro (UFRJ), Avenida Athos da Silveira 149, Bloco E, Cidade Universitária, \\ 21949-909 Rio de Janeiro, RJ, Brazil
}

Correspondence should be addressed to E. M. Del Aguila; emda@iq.ufrj.br

Received 15 November 2015; Accepted 10 February 2016

Academic Editor: Giuseppe Comi

Copyright (C) 2016 M. C. N. Carvalho et al. This is an open access article distributed under the Creative Commons Attribution License, which permits unrestricted use, distribution, and reproduction in any medium, provided the original work is properly cited.

\begin{abstract}
The bacteriological quality of crabs from three different mangroves (Itaóca, Suruí, and Piedade) from Rio de Janeiro state, Brazil, was investigated using conventional and molecular methods. The results revealed high counts for total coliforms in meat and hepatopancreas samples. PCR analyses identified 25 Escherichia coli colonies in the Itaóca, Piedade, and Suruí samples, detecting 13 enterotoxigenic colonies and 9 enteroaggregative colonies. Respectively, 12, 11, and 21 Vibrio parahaemolyticus strains were detected in the Itaóca, Piedade, and Suruí samples. Two V. cholerae strains were detected in the Piedade samples. The E. coli strains isolated in the present study showed resistance to gentamicin. E. coli strains from the Piedade samples showed $33 \%$ resistance to chloramphenicol and the strains also showed multiresistance to several antimicrobial agents with a MAR index ranging from 0.12 to 0.31 . Vibrio strains from Piedade, Itaóca, and Suruí showed $86 \%, 78 \%$, and $85 \%$ resistance, respectively, to ampicillin. The isolated Vibrio strains showed multiresistance to several antimicrobial agents, with a MAR index ranging from 0.12 to 0.25 . The presence of these organisms in crab meat is an indication of microbial contamination, which may pose health risks to consumers when improperly cooked.
\end{abstract}

\section{Introduction}

Brazil has ca. $8500 \mathrm{~km}$ of coastline with the second largest mangrove area on Earth [1]. These mangroves have suffered extensively with urbanization and industrialization in coastal regions, and, over the years, extensive ecosystems have disappeared, ending many of their important functions, such as being buffers against coastal erosion, retaining some pollutants, and being fishery areas [2].

Crabs are decapod crustaceans rich in sodium, potassium, and phosphorus with high amounts of iron, zinc, copper, and manganese. They also present high concentrations of vitamins $\mathrm{A}, \mathrm{C}, \mathrm{B} 6$, thiamine, and riboflavin and are considered a delicacy in several parts of the world [3]. Along the Brazilian coast, crabs are one of the most important natural resources in estuarine regions and can be intensely exploited without reaching an overfishing threshold, mainly because the picking method allows for the identification of the female individuals, which are of a different size compared to the males, and their release back into the environment [4].

Among the large and diverse range of mangrove products in the Brazilian north and north-eastern estuaries, the 
mangrove crab, Ucides cordatus, is the most harvested, with the highest commercial and subsistence importance to rural households of the coastal population [5]. Environment quality, as well as the mode of collection and processing of products, may affect the quantity and diversity of the microorganisms present on the surface of seafood and fishery products, which may cause increases in microbial contamination [6].

Beside the concern regarding the fecal contamination of human foods from marine ecosystems, starting in the late 1960 s various indigenous bacteria from estuarine and marine waters were also recognized as potential human pathogens. They can be concentrated in shellfish, presenting human health risks [7]. The main concern is with regard to several species of Vibrio, such as Vibrio parahaemolyticus. Recent studies have also identified shellfish as sources of Vibrio cholerae, Vibrio vulnificus, and other Vibrio species in cases of human infections [8]. Some of these human pathogens can survive and grow at the low temperatures that characterize marine ecosystems.

Vibrios are Gram-negative bacteria that are primarily associated with estuarine and coastal marine environments. A number of species have been associated with intestinal or extraintestinal infections in humans. All Vibrios have an absolute requirement of $\mathrm{Na}^{+}$for growth although some, such as $V$. cholerae, only require trace amounts. Only a small proportion of the Vibrios belong to species potentially pathogenic in humans and, of these, only a small proportion may possess the pathogenicity traits that enable them to colonize and cause disease in the human body [9].

Marine Vibrios naturally contaminating bivalve mollusks have been shown to be harder to remove by depuration than fecal bacterial indicators, such as E. coli [10]. Such processing methods may, therefore, not provide the necessary level of public health protection if significant levels of pathogenic Vibrios are present in the harvested product.

Escherichia coli is a commensal microorganism whose niche is the mucous layer of the mammalian colon. It is the most abundant facultative anaerobe of the human intestinal microflora [11]. Furthermore, E. coli is widely distributed in the intestinal tracts of warm-blooded animals [12]. E. coli is often nonpathogenic, although different strains may cause diseases in the gastrointestinal, urinary, or central nervous systems [13]. Currently, six categories of diarrheagenic E. coli have been acknowledged: enterotoxigenic E. coli (ETEC) [14], enteropathogenic E. coli (EPEC) [15], enteroinvasive $E$. coli (EIEC) [16], enterohemorrhagic E. coli (EHEC, Shiga toxin-producing E. coli or STEC) [17, 18], enteroaggregative E. coli (EAEC or EAggEc) [19], and diffusely adherent E. coli (DAEC) [20]. Despite not being very common, the isolation of diarrheagenic E. coli from seafood has been reported. In Brazil, Ayulo et al. (1994) [21] isolated only one strain of STEC from shellfish and gave evidence that preventive measures, especially during harvest and postharvest, are of major importance to avoid contamination of any nature.

Detection of pathogenic bacteria in seafood is essential to ensure safe products for consumers, sustainable fish, and shellfish growing activities. Molecular diagnostic methods have evolved significantly in the last few years and are now established as useful and reliable methods to allow the rapid detection and identification of pathogens. Molecular detection, identification, and enumeration of Vibrio spp. are largely based on PCR amplification following purification of nucleic acids from the samples. Although less sensitive and more time consuming, DNA or oligonucleotide probe-based hybridization methods have been proposed for the detection of Vibrio spp. in food [22].

Herein, the presence of potentially pathogenic isolates (Vibrio and Escherichia coli strains) from Ucides cordatus crabs from the Guanabara Bay, Rio de Janeiro, Brazil, is reported, using both conventional (biochemical identification) and molecular (PCR) methods. The antibiotic susceptibility of the isolates was also evaluated.

\section{Material and Methods}

2.1. Study Area. The mangroves selected for this study are located in Itaóca (São Gonçalo), Piedade (Mage), and Suruí (Mage), in Guanabara Bay, Rio de Janeiro, Brazil, where the gathering of this crustacean for marketing is more intense.

2.2. Sample Collection. Thirty live crabs (Ucides cordatus) were collected between March 2012 and June 2014 in each mangrove studied. These samples were analyzed at the Laboratory of Environmental Microbiology at the University of the State of Rio de Janeiro (UERJ). The crabs were washed to remove any excess sediment and other impurities present on their bodies. The viscera and meat were removed with a sterile forceps and a scalpel and placed into sterile Petri dishes. Twenty-five grams of each sample were mixed with $225 \mathrm{~mL}$ of buffered peptone water, and the suspensions were transferred to homogenizer bags (Interscience, Saint Nom, France) and coupled to a Stomacher ${ }^{\circledR} 400$ circulator (Seward, Worthing, West Sussex, UK) at $260 \mathrm{rpm}$ for $1 \mathrm{~min}$ [23]. The suspensions were serial-diluted from $10^{-6}$ to $10^{0}$ and $100 \mu \mathrm{L}$ of each dilution was transferred onto specific broths.

2.3. Microbiological Analyses of Crab Samples. The tests used for the determination of E. coli and Vibrio spp. are established in the Methods for the Microbiological Examination of Foods. The reference strains used as controls were provided by the Oswaldo Cruz Foundation, Rio de Janeiro, Brazil.

2.3.1. Fecal Coliforms Analyses. Twenty-five grams of tissue were immersed in $225 \mathrm{~mL}$ of lactose broth (Himedia ${ }^{\circledR}$, Mumbai, India) for 48 hours at $35^{\circ} \mathrm{C}$. Subsequently, $10^{-1}$ to $10^{-4}$ dilutions were carried out with $9 \mathrm{~mL}$ of saline solution for posterior inoculation in lauryl sulfate broth (Himedia, Mumbai, India) at $35^{\circ} \mathrm{C}$ for $24 \mathrm{~h}$. An $100 \mu \mathrm{L}$ aliquot of each positive tube lauryl sulfate broth (Himedia, Mumbai, India) was transferred to a corresponding tube containing $3 \mathrm{~mL}$ of EC broth (Himedia, Mumbai, India) with 5 Durham tubes for 24 hours with a series of dilutions and replicates in a water bath at $44.5^{\circ} \mathrm{C}$ [23] to determine the MPN (most probable number) coliform bacteria by counting.

2.3.2. Escherichia coli Detection. An $100 \mu \mathrm{L}$ aliquot was removed from the tube containing $3 \mathrm{~mL}$ of positive EC broth (Merck ${ }^{\circledR}$, Darmstadt, Germany) and transferred to agar plates 
containing EMB (Merck, Darmstadt, Germany). The plates were incubated for 24 hours at $37^{\circ} \mathrm{C}$. The presumptive $E$. coli spp. colonies were submitted to biochemical tests: SIM (Sulfide-Indole-Motility) (BioBrás ${ }^{\circledR}$, Minas Gerais, Brazil), citrate (Citrate of Simmons) (Difco ${ }^{\circledR}$, Sparks, Maryland, USA), and MR/VP Broth (methyl red/Voges-Proskauer) (Merck, Darmstadt, Germany) [24].

2.3.3. Vibrio spp. Detection. Twenty-five grams of crab meat and viscera were immersed in $225 \mathrm{~mL}$ of lactose broth (Himedia, Mumbai, India) for 48 hours at $35^{\circ} \mathrm{C}$ and transferred to $1 \mathrm{~mL}$ tubes containing BHI (Heart Brain Infusion) (Himedia, Mumbai, India) with $1 \%$ and $3 \%$ of $\mathrm{NaCl}$ and incubated for $24 \mathrm{~h}$ at $37^{\circ} \mathrm{C}$. A $100 \mu \mathrm{L}$ aliquot was transferred to plates containing TCBS agar (Himedia, Mumbai, India) and were incubated for $24 \mathrm{~h}$ at $37^{\circ} \mathrm{C}$. The presumptive Vibrio spp. colonies were submitted to biochemical characterization tests: oxidase test, Oxidation-Fermentation (OF) (Difco, Sparks, Maryland, USA), inositol (Difco, Sparks, Maryland, USA), and O129 (Celon-Lab ${ }^{\circledR}$, Madhapur, Hyderabad, India) [25].

\subsection{Molecular Analyses}

2.4.1. DNA Extraction. DNA preparation was carried out by the thermal shock method from all the harvested colonies. The colonies were grown in $3 \mathrm{~mL}$ of BHI broth harvested after $24 \mathrm{~h}$ at $37^{\circ} \mathrm{C}$. One $\mathrm{mL}$ of the medium was transferred to sterile Eppendorf tubes and centrifuged for $10 \mathrm{~min}$ at $12,000 \mathrm{~g}$. The supernatant was discarded and the pellet was resuspended in $400 \mu \mathrm{L}$ of pure sterile water. After homogenization, the supernatant was boiled for $10 \mathrm{~min}$, cooled on ice for $5 \mathrm{~min}$, and then collected and used for the PCR analyses [26].

2.4.2. PCR Amplification for the E. coli Virulence Gene. PCR was performed using multiplex JMS1, LT, VirA, and EAE oligos and PCR-uniplex for AggRks and EAST1 oligos (Table 1). The reactions contained a final volume of $25 \mu \mathrm{L}$ containing $5 \mu \mathrm{L}$ of template DNA, buffer (10x), $10 \mathrm{mM}$ dNTP, $25 \mathrm{mM} \mathrm{MgCl}_{2}, 2 \mathrm{U}$ Taq polymerase (Invitrogen Technologies ${ }^{\circledR}$, São Paulo, Brazil), and $10 \mathrm{mM}$ of each primer (Invitrogen Technologies, São Paulo, Brazil). The conditions of reaction were $94^{\circ} \mathrm{C}$ for $5 \mathrm{~min}, 30$ cycles of $1 \mathrm{~min}$ at $94^{\circ} \mathrm{C}, 1 \mathrm{~min}$ at $58^{\circ} \mathrm{C}, 2 \mathrm{~min}$ at $72^{\circ} \mathrm{C}$, and a final cycle of $72^{\circ} \mathrm{C}$ for $10 \mathrm{~min}$, for all reactions. PCR amplicons were visualized on $2 \%$ agarose gels stained with $3 \mu \mathrm{L}$ of ethidium bromide $\left(0.5 \mathrm{mg} \mathrm{mL}^{-1}\right)$, visualized on a UV light transilluminator (Uvitec ${ }^{\circledR}$, Cambridge, UK), and photodocumented by “Polaroid" (Canon ${ }^{\circledR}$, São Paulo, Brazil).

2.4.3. PCR Amplification for the Vibrio sp. Gene. The reaction was performed using multiplex oligos in a final volume of $20 \mu \mathrm{L}$. The mixture contained $2 \mathrm{U}$ Taq polymerase (Invitrogen Technologies, São Paulo, Brazil), 10 mM dNTPs, buffer (10x), $25 \mathrm{mM} \mathrm{MgCl}_{2}, 3 \mu \mathrm{L}$ of template DNA, and $10 \mathrm{mM}$ primers (sodB, sodB flaE, hsp, and 16S) (Table 2) [28]. The conditions of reaction were $5 \mathrm{~min}$ at $93^{\circ} \mathrm{C}$ followed by 35 cycles of $92^{\circ} \mathrm{C}$ for $40 \mathrm{~s}, 57^{\circ} \mathrm{C}$ for $1 \mathrm{~min}$, and $72^{\circ} \mathrm{C}$ for $1.5 \mathrm{~min}$ and a final cycle at $72^{\circ} \mathrm{C}$ for $7 \mathrm{~min}$, for all reactions. PCR amplicons were visualized on $2 \%$ agarose gels stained with $3 \mu \mathrm{L}$ of ethidium bromide $\left(0.5 \mathrm{mg} \mathrm{mL}^{-1}\right)$, visualized on a UV light transilluminator (Uvitec, Cambridge, UK), and photodocumented by "Polaroid” (Canon, São Paulo, Brazil).

2.5. Antibiotic Susceptibility Test. The microorganisms were inoculated at a concentration equivalent to $0.5 \mathrm{McF}$ arland units (Probac ${ }^{\circledR}$, Durban, South Africa) onto a Muller Hinton agar plate (Difco, Sparks, Maryland, USA). The antibiotic discs were placed on the plates and incubated overnight at $37^{\circ} \mathrm{C}$. The inhibition zone was interpreted according to the Clinical Laboratory Standards M100-S22 Guidelines [29], formerly known as the National Committee for Clinical Laboratory Standards. The tested antibiotics were chloramphenicol $(30 \mu \mathrm{g})$, tetracycline $(30 \mu \mathrm{g})$, gentamicin $(10 \mathrm{~g})$, amikacin $(30 \mu \mathrm{g})$, tobramycin $(10 \mathrm{~g})$, trimethoprim-sulfamethoxazole $(1.25 / 23.75 \mu \mathrm{g})$, cephalothin $(30 \mu \mathrm{g})$, ampicillin $(10 \mathrm{~g})$, ceftazidime $(30 \mu \mathrm{g})$, cefotaxime $(30 \mu \mathrm{g})$, cefepime $(30 \mu \mathrm{g})$, aztreonam $(30 \mu \mathrm{g})$, cefoxitin $(30 \mu \mathrm{g})$, imipenem (10 g), ampicillinsulbactam $(10 \mu \mathrm{g}-10 \mu \mathrm{g})$, and ciprofloxacin $(5 \mathrm{~g})$. For quality control, E. coli ATCC 25922 and E. coli ATCC 35218 were tested under the same conditions.

For strains confirmed as Vibrio spp., the test was performed according to the standard document M45-A2 [29], with the same antibiotic disks used for E. coli $\left(\right.$ Oxoid $^{\circledR}$, Hampshire, UK), with the exception of tobramycin (10 g) and aztreonam $(30 \mu \mathrm{g})$ and with the addition of levofloxacin $(5 \mathrm{~g})$ and ofloxacin ( $5 \mathrm{~g})$.

The inhibition halos were measured with the aid of a millimeter ruler.

\section{Results}

3.1. Fecal Coliforms. High concentrations of fecal coliforms $\left(6.2 \times 10^{2}\right.$ and $\left.7.2 \times 10^{2} \mathrm{NMP} \mathrm{g}^{-1}\right)$ were found in the meat and hepatopancreas samples from the Itaoca mangrove, respectively. The samples from Piedade and Suruí mangroves showed concentrations of $2.4 \times 10^{2}$ and $3.2 \times 10^{2} \mathrm{NMP} \mathrm{g}^{-1}$ in meat samples, respectively, and $2.5 \times 10^{2}$ and $3.5 \times$ $10^{2} \mathrm{NMP} \mathrm{g}^{-1}$ in hepatopancreas samples, respectively. No significant difference was observed among the thermotolerant coliform values found in the meat and hepatopancreas samples between the mangroves $(p<0.05)$.

3.2. Escherichia coli Detection. Multiplex PCR enabled the identification of 4 virulence genes (eaeA, st $x 1, l t$, and virA) in single reaction (Figure 1).

Forty-six E. coli colonies isolated from the crab samples of the different mangroves (21 from meat and 25 colonies from hepatopancreas) were confirmed by biochemical tests. After biochemical characterization, the molecular test (PCR) revealed that $25(54.3 \%)$ were positive for the researched virulence genes, 9 presenting eastA (36\%), 13 presenting $l t$ $(52 \%)$, and 3 presenting stx (12\%). No colonies presenting $\operatorname{vir} A$, eaeA, st, and agg genes were detected (Table 3 ).

Fourteen $E$. coli strains were isolated from Itaóca, with the presence of virulence genes, 2 presenting stxl (hepatopancreas), 7 presenting $l t$ ( 4 in meat and 3 in hepatopancreas), and 5 presenting east $A$ ( 4 in meat and 1 in hepatopancreas). 
TABLE 1: Primer sequences used for the identification of Escherichia coli virulence.

\begin{tabular}{|c|c|c|c|c|}
\hline Serotypes & Oligonucleotides & Gene & Sequences $\left(5^{\prime}-3^{\prime}\right)$ & Fragment size (bp) \\
\hline \multirow{2}{*}{ EPEC } & EAE-a & \multirow{2}{*}{$e a e A$} & ATG CTT AGT GCT GGT TTA GG & \multirow{2}{*}{248} \\
\hline & EAE-b & & GCC TTC ATC ATT TCG CTT TC & \\
\hline \multirow{2}{*}{ EHEC } & JMS1-F & \multirow{2}{*}{ stx1 } & GTC ACA GTA ACA AAC CGT AAC A & \multirow{2}{*}{95} \\
\hline & JMS1-R & & TCG TTG ACT ACT TCT TAT CTG GA & \\
\hline \multirow{4}{*}{ ETEC } & LT-1 & \multirow{2}{*}{ lt } & AGC AGG TTT CCC ACC GGA TCA CCA & \multirow{2}{*}{132} \\
\hline & LT1-2 & & GTG CTC AGA TTC TGG GTC TC & \\
\hline & Sta-F & \multirow{2}{*}{ st } & GCT AAT GTT GGC AAT TTT TAT TTC TGT A & \multirow{2}{*}{190} \\
\hline & Sta-R & & AGG ATT ACA ACA AAG TTC ACA GCA GTA A & \\
\hline \multirow{4}{*}{ EAEC } & Aggrks-1 & \multirow{2}{*}{$\operatorname{aggR}$} & GTA TAC ACA AAA GAA GGA AGC & \multirow{2}{*}{254} \\
\hline & Aggrks-2 & & ACA GAA TCG TCA GCA TCA GC & \\
\hline & Eastls & \multirow{2}{*}{$a s t A$} & GAG TGA CGG CTT TGT AGT CC & \multirow{2}{*}{106} \\
\hline & Eastlsa & & GCC ATC AAC ACA GTA TAT CC & \\
\hline \multirow{2}{*}{ EIEC } & VirA-F & \multirow{2}{*}{$\operatorname{vir} A$} & CTG CAT TCT GGC AAT CTC TTC ACA & \multirow{2}{*}{215} \\
\hline & VirA-R & & TGA TGA GCT AAC TTC GTA AGC CCT CC & \\
\hline
\end{tabular}

The pathotypes and virulence genes for the E. coli detected in this study are EPEC: enteropathogenic E. coli, EHEC: enterohemorrhagic E. coli, ETEC: enterotoxigenic E. coli, EAEC: enteroaggregative E. coli, and EIEC: enteroinvasive E. coli (adapted from Bisi Johnson et al. 2011 [27]).

TABLE 2: Oligonucleotide sequences used for the identification of the Vibrio genus and serotypes.

\begin{tabular}{|c|c|c|c|c|}
\hline Serotypes & Oligonucleotides & Gene & Sequences $\left(5^{\prime}-3^{\prime}\right)$ & Fragment size (bp) \\
\hline \multirow{2}{*}{ Vibrio spp. } & V.16S-700F & \multirow{2}{*}{$16 S$} & CGG TGA AAT GCG TAG AGA T & \multirow{2}{*}{663} \\
\hline & V.16S1325R & & TTA CTA GCG ATT CCG AGT TC & \\
\hline \multirow{2}{*}{ V. cholerae } & Vc.sodB-F & \multirow{2}{*}{$\operatorname{sod} B$} & AAG ACC TCA ACT GGC GGT A & \multirow{2}{*}{248} \\
\hline & Vc.sodB-R & & GAA GTG TTA GTG ATC GCC AGA GT & \\
\hline \multirow{2}{*}{ V. mimicus } & Vm.sodB-F & \multirow{2}{*}{$\operatorname{sod} B$} & CAT TCG GTT CTT TCG CTG AT & \multirow{2}{*}{121} \\
\hline & Vm.sodB-R2 & & GAA GTG TTA GTG ATT GCT AGA GAT & \\
\hline \multirow{2}{*}{$V \cdot$ parahaemolyticus } & Vp.flaE-79F & \multirow{2}{*}{ flaE } & GCA GCT GAT CAA AAC GTT GAG T & \multirow{2}{*}{897} \\
\hline & Vp.flae-934R & & ATT ATC GAT CGT GCC ACT CAC & \\
\hline \multirow{2}{*}{ V. vulnificus } & Vv.hsp-326F & \multirow{2}{*}{$h s p$} & GTC TTA AAG CGG TTG CTG C & \multirow{2}{*}{410} \\
\hline & Vv.hsp-697R & & CGC TTC AAG TGC TGG TAG AAG & \\
\hline
\end{tabular}

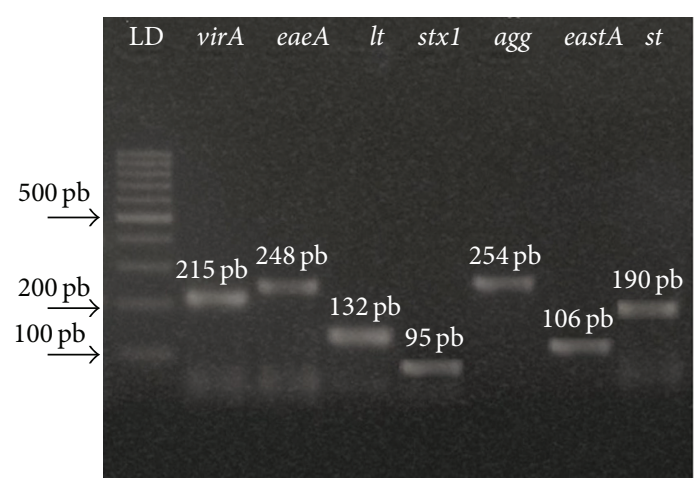

FIGURE 1: Specific amplicons of E. coli virulence genes. E. coli virulence gene (virA), enteroinvasive E. coli (eaeA), enteropathogenic $E$. coli ( $l t$ and $s t$ ), enterotoxigenic E. coli (stxl), enterohemorrhagic $E$. coli (astA), and enteroaggregative E. coli (agg).

Eight strains were detected in samples from the Suruí mangrove, where 4 strains showed the $l t$ virulence gene (2 in meat and 2 in hepatopancreas) and 4 strains showed the east virulence gene ( 2 in meat and 2 in hepatopancreas). Thirteen
TABLE 3: Expression of E. coli virulence genes by PCR distributed by mangrove.

\begin{tabular}{lcccc}
\hline Strains & Gene & $\begin{array}{c}\text { Itaóca } \\
(n=14)\end{array}$ & $\begin{array}{c}\text { Piedade } \\
(n=3)\end{array}$ & $\begin{array}{c}\text { Suruí } \\
(n=8)\end{array}$ \\
\hline Enteropathogenic & $e a e A$ & 0 & 0 & 0 \\
Enterohemorrhagic & $s t x 1$ & 2 & 1 & 0 \\
Enterotoxigenic & $l t$ & 7 & 2 & 4 \\
Enteroaggregative & agg & 0 & 0 & 0 \\
Enteroinvasive & eastA & 5 & 0 & 0 \\
\hline
\end{tabular}

strains were detected in the samples from the Piedade mangrove by means of the biochemical test, but only one showed the presence of the st $x 1$ virulence gene (meat), while 2 showed the presence of the $l t$ virulence gene (hepatopancreas).

3.3. Vibrio spp. Detection. Suruí mangrove samples showed the highest incidence of isolated Vibrio (46), followed by 
TABLE 4: Distribution of Vibrio strains by mangrove.

\begin{tabular}{|c|c|c|c|c|c|}
\hline \multirow{2}{*}{ Strains } & \multirow{2}{*}{ Gene } & \multicolumn{3}{|c|}{ Mangrove } & \multirow[b]{2}{*}{ Total $(n=119)$} \\
\hline & & Itaóca $(n=33)$ & Piedade $(n=40)$ & Suruí $(n=46)$ & \\
\hline Vibrio spp. & $16 S$ & 21 & 27 & 25 & 73 \\
\hline V. cholerae & $\operatorname{sod} B$ & 0 & 02 & 0 & 02 \\
\hline V. parahaemolyticus & flaE & 12 & 11 & 21 & 44 \\
\hline V. mimicus & $\operatorname{sod} B 1$ & 0 & 0 & 0 & 0 \\
\hline V. vulnificus & $h s p$ & 0 & 0 & 0 & 0 \\
\hline
\end{tabular}

$n$ : number of strains.

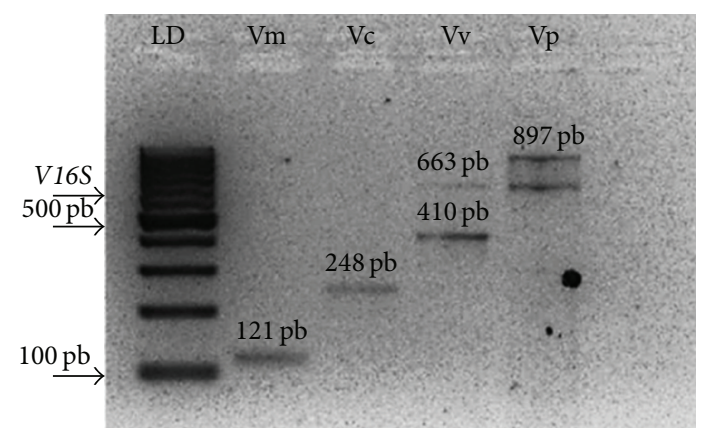

Figure 2: Amplicons of specific Vibrio genes. LD: molecular marker; Vm: V. mimicus, Vc: V. cholerae, Vv: V. vulnificus, and Vp: V. parahaemolyticus.

Piedade (40) and Itaóca (33). One hundred and nineteen Vibrio strains were confirmed by PCR in 90 samples (meat: 68, and hepatopancreas: 51). The present study identified 5 different genes, one for the Vibrio spp. genus and 4 for species (Figure 2). A similar study was carried out by Teh et al. (2010) [30] using multiplex PCR (identifying the gyrB and $p n t A$ genes) to differentiate $V$. parahaemolyticus, $V$. cholerae, $V$. vulnificus, and other Vibrio spp. from fish.

Among the researched Vibrio genus, 61.3\% (73/119) of the samples were detected using only the $16 \mathrm{~S}$ gene for the Vibrionaceae family. Pathogenic strains V. cholerae and $V$. parahaemolyticus were found with a frequency of $1.7 \%$ $(02 / 119)$ and $37 \%(44 / 119)$, respectively (Table 4$)$. V. cholerae was only detected in the crab samples from Piedade mangrove. The highest incidence of $V$. parahaemolyticus was observed in samples from the Suruí mangrove (21), followed by Itaóca (12) and Piedade (11).

No $V$. mimicus and $V$. vulnificus were detected in the present study (Table 4).

3.4. Antimicrobial Susceptibility Test. The resistance results are displayed in Table 5. Twenty-six E. coli strains showed some resistance to the tested antimicrobials, with a high index of resistance. E. coli strains isolated from the Itaóca samples showed high resistance (63\%) against gentamicin (CN) and tobramycin (TOB).

E. coli strains found at Piedade, Itaóca, and Suruí showed resistance to gentamicin $(66 \%, 63 \%$, and $22 \%$, resp.). The E. coli isolates from the Piedade samples showed $33 \%$ resistance to chloramphenicol (C). Only strains found in crabs from the Piedade mangrove showed resistance (16\%) to ampicillin (AMP). No resistance to amoxicillin + clavulanic acid (AMC), levofloxacin (LEV), cefoxitin (CTX), ofloxacin (OFX), and ciprofloxacin (CIP) was observed.

Among the 26 resistant E. coli strains, 12 were resistant to two or more antibiotics (Table 6). This pattern is mainly due to the indiscriminate use of antimicrobials and may cause serious impacts on human health [31, 32]. The E. coli strains showed multiresistance to several antimicrobial agents, with MAR indices ranging from 0.12 to 0.31 , whereas 3 strains showed MAR indexes from 0.12 to 0.25 and 3 strains presented MAR indexes of 0.18 (Table 6). The resistance of the 26 E. coli strains was distributed as follows: 12 strains were resistant to gentamicin and tobramycin, 4 were resistant to amikacin and cephalothin, 3 were resistant to ciprofloxacin, tetracycline, ceftazidime, and cefoxitin, and one strain was resistant to ampicillin.

When 119 Vibrio strains were analyzed only 72 isolates (60.5\%) showed resistance to some of the tested antimicrobials, with higher rates in those isolated from crabs samples from Piedade (29), followed by Itaóca (23) and Surui (20) (Table 5). The Vibrio strains from Piedade, Itaóca, and Suruí showed resistance to ampicillin (86\%, $78 \%$, and $85 \%$, resp.). The strains from Surui showed 5\% resistance to amoxicillin + clavulanic acid (AMC), ampicillin/sulbactam (SAM), and chloramphenicol (C). The Piedade strains showed resistance to levofloxacin (LEV) and ciprofloxacin (CIP). No resistance to cefoxitin (CTX), ceftazidime (CAZ), tobramycin (TOB), and tetracycline (TE) was observed.

Vibrio strains isolated from crabs showed multiresistance to several antimicrobial agents, presenting a MAR index ranging from 0.12 to $0.25 ; 24$ strains presented MAR indices of 0.12 (Table 6); 5 strains showed MAR indices of 0.18; and two strains showed MAR indices of 0.25 MAR indexes.

The resistance of the 72 strains was distributed as follows: 60 strains were resistant to ampicillin, 14 were resistant to amikacin (AK), 10 were resistant to cephalothin (KF), 8 were resistant to cefoxitin (CTX), 5 were resistant to gentamicin $(\mathrm{CN}), 3$ were resistant to ciprofloxacin (CIP), and 1 strain was resistant to amoxicillin + clavulanic (AMC), ampicillin + sulbactam (SAM), levofloxacin (LEV), ofloxacin (OFX), and chloramphenicol (C).

\section{Discussion}

The thermotolerant coliforms found in the present study are above the maximum permissible limit (maximum tolerance 
TABLE 5: E. coli and Vibrio resistance of strains isolated from crab to the tested antimicrobials.

\begin{tabular}{|c|c|c|c|c|c|c|}
\hline \multirow{2}{*}{$\begin{array}{l}\text { Antimicrobial } \\
\text { agent resistance }\end{array}$} & \multicolumn{3}{|c|}{ E. coli } & \multicolumn{3}{|c|}{ Vibrio } \\
\hline & Itaóca $(n=11)$ & Piedade $(n=06)$ & Suruí $(n=09)$ & Itaóca $(n=23)$ & Piedade $(n=29)$ & Suruí $(n=20)$ \\
\hline AMP & - & $16 \%$ & - & $78 \%$ & $86 \%$ & $85 \%$ \\
\hline $\mathrm{AMC}$ & - & - & - & - & - & $5 \%$ \\
\hline SAM & - & $16 \%$ & $11 \%$ & - & - & $5 \%$ \\
\hline $\mathrm{KF}$ & $19 \%$ & $16 \%$ & $11 \%$ & $8 \%$ & $17 \%$ & $15 \%$ \\
\hline CTX & - & - & - & $13 \%$ & $17 \%$ & - \\
\hline $\mathrm{CN}$ & $63 \%$ & $66 \%$ & $22 \%$ & $4 \%$ & $6 \%$ & $10 \%$ \\
\hline $\mathrm{CFO}$ & $9 \%$ & $16 \%$ & - & - & - & - \\
\hline CAZ & $9 \%$ & $16 \%$ & - & - & - & - \\
\hline LEV & - & - & - & - & $3 \%$ & - \\
\hline OFX & - & - & - & $4 \%$ & - & - \\
\hline TOB & $63 \%$ & $66 \%$ & $22 \%$ & - & - & - \\
\hline $\mathrm{AK}$ & - & $33 \%$ & $22 \%$ & $17 \%$ & $24 \%$ & $15 \%$ \\
\hline $\mathrm{TE}$ & - & $16 \%$ & $11 \%$ & - & - & - \\
\hline CIP & - & - & - & - & $3 \%$ & $10 \%$ \\
\hline $\mathrm{C}$ & $9 \%$ & $33 \%$ & - & - & - & $5 \%$ \\
\hline
\end{tabular}

$n$ : number of tested strains. AMP: ampicillin; AMC: amoxicillin + clavulanic acid; SAM: ampicillin/sulbactam; KF: cephalothin; CTX: cefotaxime; CFO: cefoxitin; CAZ: ceftazidime; LEV: levofloxacin; CIP: ciprofloxacin; OFX: ofloxacin; CN: gentamicin; TOB: tobramycin; AK: amikacin; TE: tetracycline; C: chloramphenicol.

of $5 \times 10^{1} \mathrm{NMP} \mathrm{g}^{-1}$ for coliforms at $45^{\circ} \mathrm{C}$ ) in bivalve mollusks, crab meat, and similar samples, according to laws from the Brazilian Sanitary Vigilance Agency (Agência Nacional de Vigilância Sanitária (ANVISA)) [33]. Similar results were found with regard to the microbiological quality of Úça crab meat in 3 different points at Praia do Futuro, located in Fortaleza, CE, Brazil, where thermotolerant coliforms were detected ranging from 3.0 to $1,100 \mathrm{NMP} \mathrm{g}^{-1}$ in 90 analyzed crabs [34]. According to de Lima Grisi and Gorlach-Lira (2010) [35], the presence of this group of bacteria is associated to the dumping of fecal material in the environment. Guanabara Bay receives effluents without treatment daily and has become bacteria reservoir, which in turn has caused the contamination of fish and other biota in this region [36].

The expression of $E$. coli virulence genes is a public health risk, since these genes characterize the presence of toxins able to cause disease. E. coli cells are the main pathogens associated to gastroenteritis of food origin in humans, provoking diarrhea, hemorrhagic colitis, and hemolytic-uremic syndrome [37]. However, some studies reporting human infection by $E$. coli due to crab consumption are available [38]. Despite the absence of the virA, eae, st, and agg genes in the present study, the confirmation of $E$. coli strains indicates recent fecal contamination in crabs, and this indicates that major care in the preparation of this type of food is required.

The results regarding the presence of Vibrio can be explained by the salinity and temperature of the studied mangroves [39]. Many studies show the presence of Vibrio in aquatic animals such as fish [40], shrimp [41], and mussels [42], but, despite the importance of crabs, only some studies have been conducted on crab contamination by Vibrio. However, its occurrence in marine food is pointed as a major cause of gastroenteritis in the United States and Europe [43] and associated with cases in Brazil and Chile [44]. These results suggest a probable health risk for people that consume raw and undercooked seafood. According to Alam et al. (2012) [45], V. vulnificus and V. mimicus are most commonly found in coccoid viable but not culturable form, while another study confirmed the presence of Vibrio in crabs marketed in Fortaleza, Brazil, where only 10 strains were identified up to the species level: $2 \mathrm{~V}$. alginolyticus and $8 \mathrm{~V}$. parahaemolyticus but not any $V$. vulnificus and V. mimicus [4]. Abd-Elghany and Sallam (2013) [46] detected 10 V. parahaemolyticus isolates in crab by molecular identification in Egypt and highlighted that reliable molecular detection methods should be included in routine seafood examinations, in addition to the conventional bacteriological methods.

These findings of antimicrobial susceptibility are in agreement with data from previous studies, which found that resistance to aminoglycosides, $\beta$-lactamase, and penicillin is common among $E$. coli isolates from food of animal origin [47-49]. However, the resistance frequency in E. coli isolated in the present study was low when compared to other studies, where a resistance of $58 \%$ and $42 \%$ in raw fish samples from Kenya and Vietnam, respectively, was observed $[48,50]$. Mussel samples from Niterói (Brazilian Southeastern oceanic region) showed $29 \%$ resistance to at least one antimicrobial [31], and strains isolated from mussels from the Guanabara Bay, Rio de Janeiro, showed $40 \%$ to $85 \%$ resistance to tested antimicrobials [51], indicating the intense presence of domestic and industrial effluents. The percentage of high sensitivity to these antibiotics was also observed by Rebouças et al. (2011) [41] in strains isolated from shellfish and is associated with various resistance mechanisms found in Gram-negative organisms. Over time, Vibrio strains exposed to antibiotics through the environment can acquire antimicrobial 
TABle 6: Multiple antimicrobial resistance of E. coli and Vibrio strains found in crab.

\begin{tabular}{lcc}
\hline & Antimicrobial resistance & MAR index \\
\hline E. coli & CN, TOB & \\
$(3)$ & CFO, TOB & 0.12 \\
$(1)$ & CN, KF, TOB & 0.12 \\
$(1)$ & AK, CN, TOB & 0.18 \\
$(2)$ & C, CAZ, CN, TOB & 0.18 \\
$(1)$ & C, CN, KF, SAM & 0.25 \\
$(1)$ & CN, CFO, KF, TOB & 0.25 \\
$(1)$ & AK, AMP, C, CAZ, CN, TOB & 0.25 \\
$(1)$ & AK, CN, KF, SAM, TE, TOB & 0.31 \\
$(1)$ & & 0.31 \\
Vibrio & AK, AMP & \\
$(14)$ & AMP, KF & 0.12 \\
$(6)$ & AK, KF & 0.12 \\
$(2)$ & CTX, KF & 0.12 \\
$(2)$ & AK, CN, CTX & 0.12 \\
$(2)$ & AK, CTX, KF & 0.18 \\
$(1)$ & CN, CTX, KF & 0.18 \\
$(2)$ & AK, CIP, KF, LEV & 0.18 \\
$(1)$ & AK, CTX, CN, KF & 0.25 \\
$(1)$ & & 0.25 \\
\hline
\end{tabular}

The MAR (multiple antimicrobial resistance) index of an isolate is defined as $a / b$, where $a$ represents the number of antibiotics to which the isolate was resistant and $b$ represents the number of antibiotics to which the isolate was subjected. AK: amikacin; AMP: ampicillin; AMC: amoxicillin + clavulanic acid; C: chloramphenicol, CAZ: ceftazidime; CFO: cefoxitin; CIP: ciprofloxacin; CN: gentamicin; CTX: cefoxitin; KF: cephalothin; LEV: levofloxacin; OFX: ofloxacin; SAM: ampicillin/sulbactam; TOB: tobramycin; TE: tetracycline.

resistance transferable by mobile genetic elements and horizontal gene transfer [52]. Thus, due to the presence of Rfactors in the population, resistance developed through gene regulation of plasmids and chromosomes may be transferred vertically (by heredity) or horizontally [53]. In the present study, ampicillin was an antibiotic that showed low efficiency against the 60 tested Vibrio spp. strains (83.3\%). According to the standard CLSI M45-A2 [54], species belonging to the Vibrio genus have intrinsic resistance to ampicillin. This data was confirmed in another study, where, from 169 Vibrio strains isolated from shrimp, only 3 were sensitive to ampicillin [55]. The high percentage of pathogenic Vibrio with reduced susceptibility to ampicillin suggests a potential for the low efficiency of ampicillin in the treatment of Vibrio infections [56].

Many cases of multiple antimicrobial resistance have been reported from shellfish farms in countries where the activity is well developed, such as China [57], Korea [58], and Chile [59]. According to the World Health Organization, changes in the microbiota can induce the evolution of new pathogenic microorganisms and the development of new virulence factors in ancient pathogens, such as the development of resistance to antimicrobials or changes in their survival ability in adverse environmental conditions [60].

\section{Conclusions}

Several E. coli and Vibrio isolates were found in crabs (Ucides cordatus) from different mangroves in the state of Rio de Janeiro, Brazil. Considering the current legislation, the presence of these pathogens in crab indicates contamination influenced by mangrove pollution, by using newer molecular methods and thus contributing to seafood safety. Some isolated strains showed differential resistance to antimicrobials. The analyzed samples presented unsuitable hygienic-sanitary conditions, which can be considered a warning to the Municipal Health Surveillance Agency, since seafood is many times consumed without any subsequent thermal treatment or even sufficient thermal treatment able to eliminate pathogenic microorganisms, causing disorders to consumer health.

\section{Competing Interests}

The authors declare that they have no competing interests.

\section{Authors' Contributions}

M. C. N. Carvalho carried out the laboratory study and the interpretation of the data under the supervision of $\mathrm{F}$. V. Araújo, S. G. F. Leite, and E. M. Del Aguila. M. M. Jayme and G. S. Arenazio collected the samples and participated in the microbiological analyses. E. M. Del Aguila edited the paper. All authors read and approved the final paper.

\section{Acknowledgments}

The authors acknowledge the financial support from the Conselho Nacional de Desenvolvimento Científico e Tecnológico $(\mathrm{CNPq}$, Brasília, Brazil) and Coordenação de Aperfeiçoamento de Pessoal de Nível Superior (CAPES, Brasília, Brazil).

\section{References}

[1] B. Kjerfve, Mangrove Ecosystem Studies in Latin America and Africa, UNESCO, Paris, France, 1997.

[2] U. Cotano and F. Villate, "Anthropogenic influence on the organic fraction of sediments in two contrasting estuaries: a biochemical approach," Marine Pollution Bulletin, vol. 52, no. 4, pp. 404-414, 2006.

[3] R. H. S. F. Vieira, E. A. De Lima, D. B. R. Sousa, E. F. Dos Reis, R. G. Costa, and D. D. P. Rodrigues, "Vibrio spp. and Salmonella spp., presence and susceptibility in crabs Ucides cordatus," Revista do Instituto de Medicina Tropical de São Paulo, vol. 46, no. 4, pp. 179-182, 2004.

[4] P. Nishidha, "Nutritional Values of Crabs," 2016, http://www .organicfacts.net/.

[5] G. Dallabona, J. de Loyola e Silva, and M. A. A. Pinheiro, "Size at morphological maturity of Ucides cordatus (Linnaeus, 1763) (Brachyura, Ocypodidae) in the Laranjeiras Bay, Southern Brazil," Brazilian Archives of Biology and Technology, vol. 48, no. 1, pp. 139-145, 2005.

[6] C. A. Ristori, S. T. Iaria, D. S. Gelli, and I. N. G. Rivera, "Pathogenic bacteria associated with oysters (Crassostrea brasiliana) 
and estuarine water along the south coast of Brazil," International Journal of Environmental Health Research, vol. 17, no. 4, pp. 259-269, 2007.

[7] D. L. Tion and R. J. Seidler, "Vibrio aestuarianus: a new species from estuarine waters and shellfish," International Journal of Systematic Bacteriology, vol. 33, no. 4, pp. 699-702, 1983.

[8] J. M. Hughes, D. G. Hollis, E. J. Gangarosa, and R. E. Weaver, "Non-cholera Vibrio infections in the United States: clinical, epidemiologic, and laboratory features," Annals of Internal Medicine, vol. 88, no. 5, pp. 602-606, 1978.

[9] R. J. Lee and R. E. Rangdale, Improving Seafood Products for the Consumer, vol. 158 of Woodhead Publishing Series in Food Science, Technology and Nutrition, Woodhead Publishing, Cambridge, UK, 1st edition, 2008, edited by: T. Borresen.

[10] G. E. Rodrick and K. R. Schneider, "Vibrios in depuration," in Molluscan Shellfish Depuration, W. S. Otwell, G. E. Rodrick, and R. E. Martin, Eds., pp. 115-125, CRC Press, Boca Raton, Fla, USA, 1991.

[11] J. B. Kaper, J. P. Nataro, and H. L. T. Mobley, "Pathogenic Escherichia coli," Nature Reviews Microbiology, vol. 2, no. 2, pp. 123140, 2004.

[12] S. Ishii and M. J. Sadowsky, "Escherichia coli in the environment: implications for water quality and human health," Microbes and Environments, vol. 23, no. 2, pp. 101-108, 2008.

[13] J. P. Nataro and J. B. Kaper, "Diarrheagenic Escherichia coli," Clinical Microbiology Reviews, vol. 11, no. 1, pp. 142-201, 1998.

[14] C. B. Dalton, E. D. Mintz, J. G. Wells, C. A. Bopp, and R. V. Tauxe, "Outbreaks of enterotoxigenic Escherichia coli infection in American adults: a clinical and epidemiologic profile," Epidemiology and Infection, vol. 123, no. 1, pp. 9-16, 1999.

[15] M.-H. Ruchaud-Sparagano, M. Maresca, and B. Kenny, "Enteropathogenic Escherichia coli (EPEC) inactivate innate immune responses prior to compromising epithelial barrier function," Cellular Microbiology, vol. 9, no. 8, pp. 1909-1921, 2007.

[16] M. M. Levine, "Escherichia coli that cause diarrhea: enterotoxigenic, enteropathogenic, enteroinvasive, enterohemorrhagic, and enteroadherent," The Journal of Infectious Diseases, vol. 155, no. 3, pp. 377-389, 1987.

[17] Y. Takeda, "Vibrio parahaemolyticus, enterotoxigenic Escherichia coli, enterohemorrhagic Escherichia coli and Vibrio cholerae," Proceedings of the Japan Academy. Series B, vol. 87, no. 1, pp. 1-12, 2011.

[18] H. S. Kumar, S. K. Otta, I. Karunasagar, and I. Karunasagar, "Detection of Shiga-toxigenic Escherichia coli (STEC) in fresh seafood and meat marketed in Mangalore, India by PCR," Letters in Applied Microbiology, vol. 33, no. 5, pp. 334-338, 2001.

[19] C. S. Beauchamp and N. J. Sofos, "Diarrheagenic Escherichia coli," in Pathogens and Toxins in Foods, V. K. Juneja and J. N. Sofos, Eds., pp. 71-94, ASM Press, Washington, DC, USA, 2010.

[20] I. C. A. Scaletsky, S. H. Fabbricotti, R. L. B. Carvalho et al., "Diffusely adherent Escherichia coli as a cause of acute diarrhea in young children in northeast Brazil: a case-control study," Journal of Clinical Microbiology, vol. 40, no. 2, pp. 645-648, 2002.

[21] A. M. R. Ayulo, R. A. Machado, and V. M. Scussel, "Enterotoxigenic Escherichia coli and Staphylococcus aureus in fish and seafood from the southern region of Brazil," International Journal of Food Microbiology, vol. 24, no. 1-2, pp. 171-178, 1994.

[22] R. A. Amin and A. M. Salem, "Specific detection of pathogenic Vibrio species in shellfish by using multiplex polymerase chain reaction," Global Veterinaria, vol. 8, no. 5, pp. 525-531, 2012.
[23] APHA (American Public Health Association), Standard Methods for the Examination of Water and Wastewater, APHA, Washington, DC, USA, 21th edition, 2005.

[24] P. Feng, S. D. Weagant, M. A. Grant, and W. Burkhardt, "Enumeration of Escherichia coli and the Coliform bacteria," in Bacteriological Analytical Manual, US Food Drugs, 2002, http:// www.fda.gov/Food/FoodScienceResearch/LaboratoryMethods/ ucm064948.htm.

[25] A. De Paola and C. Kysner, "Vibrio," in Bacteriological Analytical Manual, FDA, 2011, http://www.fda.gov/Food/FoodScienceResearch/LaboratoryMethods/ucm070830.htm.

[26] L. R. Santos, "Identificação de Salmonella através da reação em cadeia pela polimerase (PCR)," Arquivos da Faculdade Veterinaria de UFRGS, vol. 28, pp. 87-92, 2001.

[27] M. A. Bisi-Johnson, C. L. Obi, S. D. Vasaikar, K. A. Baba, and T. Hattori, "Molecular basis of virulence in clinical isolates of Escherichia coli and Salmonella species from a tertiary hospital in the Eastern Cape, South Africa," Gut Pathogens, vol. 3, no. 1, article 9, 8 pages, 2011.

[28] C. L. Tarr, J. S. Patel, N. D. Puhr, E. G. Sowers, C. A. Bopp, and N. A. Strockbine, "Identification of Vibrio isolates by a multiplex PCR assay and rpoB sequence determination," Journal of Clinical Microbiology, vol. 45, no. 1, pp. 134-140, 2007.

[29] CLSI, Performance Standards for Antimicrobial Susceptibility Testing: Twenty-Second Informational Supplement, CLSI Document M100-S22, Clinical and Laboratory Standards Institute, Wayne, Pa, USA, 11th edition, 2012.

[30] C. S. J. Teh, K. H. Chua, and K. L. Thong, "Simultaneous differential detection of human pathogenic and nonpathogenic Vibrio species using a multiplex PCR based on gyrB and pntA genes," Journal of Applied Microbiology, vol. 108, no. 6, pp. 1940$1945,2010$.

[31] M. M. A. Jayme, Avaliação microbiológica, detecção e susceptibilidade a antimicrobianos de potenciais enteropatógenos das famílias Enterobacteriaceae e Vibrionaceae em mexilhões Perna perna da praia de Itaipu, Niterói-RJ [M.S. thesis], Universidade do Estado do Rio de Janeiro, Faculdade de Ciências Médicas, 2014.

[32] N. S. Evangelista-Barreto, A. F. Pereira, R. A. R. Da Silva, and L. T. B. Ferreira, "Carne de siri como veículo na disseminação de enteropatógenos resistentes aos antimicrobianos," Acta Pesca, vol. 1, pp. 45-56, 2013.

[33] Agência Nacional de Vigilância Sanitária (ANVISA), Resolução-RDC n'12, de 02 de Janeiro de 2001, Regulamento Técnico sobre Padrões Microbiológicos para Alimentos, Agência Nacional de Vigilância Sanitária (ANVISA), Brasília, Brazil, 2001.

[34] A. J. G. Araújo, C. O. Brandão, F. C. T. Carvalho, and R. H. S. F. Vieira, "Qualidade microbiológica do caranguejo-uçá exposto à venda em três pontos na orla da Praia do Futuro, FortalezaCE-Brasil," Boletim do Instituto de Pesca, vol. 37, pp. 409-416, 2011.

[35] T. C. S. de Lima Grisi and K. Gorlach-Lira, "The abundance of some pathogenic bacteria in mangrove habitats of paraiba do norte estuary and crabmeat contamination of mangrove crab ucides cordatus," Brazilian Archives of Biology and Technology, vol. 53, no. 1, pp. 227-234, 2010.

[36] J. A. Neto and E. M. Fonseca, "Variação sazonal, espacial e composicional de lixo ao longo das praias da margem oriental da Baía de Guanabara (Rio de Janeiro) no período de 1999-2008," Journal of Integrated Coastal Zone Management, vol. 11, no. 1, pp. 31-39, 2011. 
[37] O. E. Ojo, A. T. P. Ajuwape, E. B. Otesile, A. A. Owoade, M. A. Oyekunle, and A. I. Adetosoye, "Potentially zoonotic shiga toxin-producing Escherichia coli serogroups in the faeces and meat of food-producing animals in Ibadan, Nigeria," International Journal of Food Microbiology, vol. 142, no. 1-2, pp. 214-221, 2010.

[38] P. Matulkova, M. Gobin, J. Taylor, F. Oshin, K. O'Connor, and I. Oliver, "Crab meat: a novel vehicle for E. coli O157 identified in an outbreak in South West England," Epidemiology and Infection, vol. 141, no. 10, pp. 2043-2050, 2013.

[39] B. Austin, "Vibrios as causal agents of zoonoses," Veterinary Microbiology, vol. 140, no. 3-4, pp. 310-317, 2010.

[40] U. Messelhäusser, J. Colditz, D. Thärigen, W. Kleih, C. Höller, and U. Busch, "Detection and differentiation of Vibrio spp. in seafood and fish samples with cultural and molecular methods," International Journal of Food Microbiology, vol. 142, no. 3, pp. 360-364, 2010.

[41] R. H. Rebouças, O. V. De Sousa, A. S. Lima, F. R. Vasconcelos, P. B. De Carvalho, and R. H. S. Dos Fernandes-Vieira, "Antimicrobial resistance profile of Vibrio species isolated from marine shrimp farming environments (Litopenaeus vannamei) at Ceará, Brazil," Environmental Research, vol. 111, no. 1, pp. 2124, 2011.

[42] S. K. Lhafi and M. Kühne, "Occurrence of Vibrio spp. in blue mussels (Mytilus edulis) from the German Wadden Sea," International Journal of Food Microbiology, vol. 116, no. 2, pp. 297300, 2007.

[43] C. A. M. L. D. Santos and R. H. S. F. Vieira, "Bacteriological hazards and risks associated with seafood consumption in Brazil," Revista do Instituto de Medicina Tropical de São Paulo, vol. 55, no. 4, pp. 219-228, 2013.

[44] E. Harth, L. Matsuda, C. Hernández et al., "Epidemiology of Vibrio parahaemolyticus outbreaks, southern Chile," Emerging Infectious Diseases, vol. 15, no. 2, pp. 163-168, 2009.

[45] M. Alam, M. T. Islam, S. M. Rashed et al., "Vibrio cholerae classical biotype strains reveal distinct signatures in Mexico," Journal of Clinical Microbiology, vol. 50, no. 7, pp. 2212-2216, 2012.

[46] S. M. Abd-Elghany and K. I. Sallam, "Occurrence and molecular identification of Vibrio parahaemolyticus in retail shellfish in Mansoura, Egypt," Food Control, vol. 33, no. 2, pp. 399-405, 2013.

[47] A. Jouini, K. B. Slama, Y. Sáenz et al., "Detection of multipleantimicrobial resistance and characterization of the implicated genes in Escherichia coli isolates from foods of animal origin in Tunis," Journal of Food Protection, vol. 72, no. 5, pp. 1082-1088, 2009.

[48] T. T. H. Van, J. Chin, T. Chapman, L. T. Tran, and P. J. Coloe, "Safety of raw meat and shellfish in Vietnam: an analysis of Escherichia coli isolations for antibiotic resistance and virulence genes," International Journal of Food Microbiology, vol. 124, no. 3, pp. 217-223, 2008.

[49] A. Vasilakopoulou, M. Psichogiou, L. Tzouvelekis et al., "Prevalence and characterization of class 1 integrons in Escherichia coli of poultry and human origin," Foodborne Pathogens and Disease, vol. 6, no. 10, pp. 1211-1218, 2009.

[50] A. W. Sifuna, N. M. Njagi, P. Okemo, A. Munyalo, G. O. Orinda, and S. Kariuki, "Microbiological quality and safety of Rastrineobola argentea retailed in Kisumu town markets, Kenya," East African Medical Journal, vol. 85, pp. 509-513, 2009.

[51] A. M. Valente, Efeito da irradiação sobre mexilhões [Perna perna (Linnaeus 1758)]: coliformes termotolerantes e enterococcus; ação antimicrobiana e análise sensorial das amostras [Master Dissertation], Universidade Federal Fluminense, Niterói, Brazil, 2004.

[52] K. Kümmerer, "Antibiotics in the aquatic environment-a review-part II," Chemosphere, vol. 75, no. 4, pp. 435-441, 2009.

[53] M. T. Madigan, J. M. Martinko, J. Parker, M. G. Fernández, C. R. Fernández, and M. S. Pérez, Brock Biology of Microorganisms, Pearson Education, Upper Saddle River, NJ, USA, 2003.

[54] CLSI, Methods for Antimicrobial Dilution and Disk Susceptibility Testing of Infrequently Isolated or Fastidious Bacteria; Approved Guideline, CLSI Document M45-A2, Clinical and Laboratory Standards Institute, Wayne, Pa, USA, 2nd edition, 2010.

[55] H. Ji, Y. Chen, Y. Guo, X. Liu, J. Wen, and H. Liu, "Occurrence and characteristics of Vibrio vulnificus in retail marine shrimp in China," Food Control, vol. 22, no. 12, pp. 1935-1940, 2011.

[56] S. Sudha, C. Mridula, R. Silvester, and A. A. M. Hatha, "Prevalence and antibiotic resistance of pathogenic Vibrios in shellfishes from Cochin market," Indian Journal of Geo-Marine Sciences, vol. 43, no. 5, pp. 815-824, 2014.

[57] H. Dang, X. Zhang, L. Song, Y. Chang, and G. Yang, "Molecular characterizations of oxytetracycline resistant bacteria and their resistance genes from mariculture waters of China," Marine Pollution Bulletin, vol. 52, no. 11, pp. 1494-1503, 2006.

[58] H. Y. Kang, Y. S. Jeong, J. Y. Oh et al., "Characterization of antimicrobial resistance and class 1 integrons found in Escherichia coli isolates from humans and animals in Korea," Journal of Antimicrobial Chemotherapy, vol. 55, no. 5, pp. 639-644, 2005.

[59] C. D. Miranda and R. Rojas, "Occurrence of florfenicol resistance in bacteria associated with two Chilean salmon farms with different history of antibacterial usage," Aquaculture, vol. 266, no. 1-4, pp. 39-46, 2007.

[60] World Health Organization (WHO), "Food Safety and Foodborne Illness," 2016, http://www.who.int/mediacentre/factsheets/fs399/en/. 

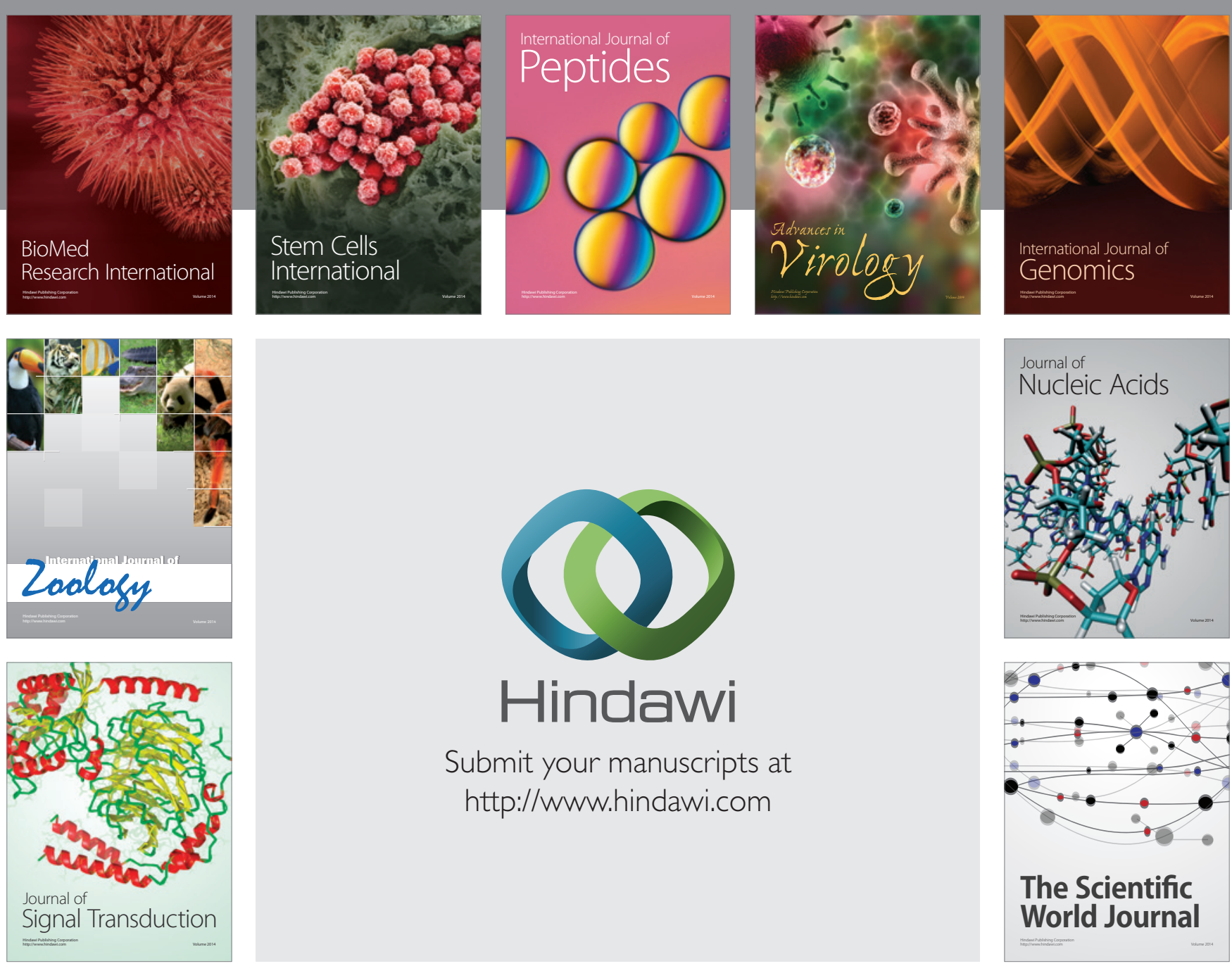

Submit your manuscripts at

http://www.hindawi.com
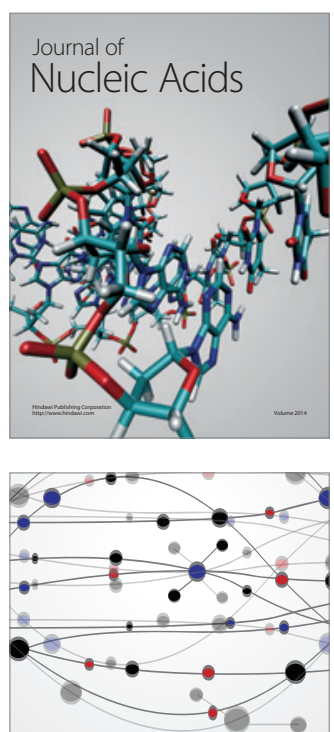

The Scientific World Journal
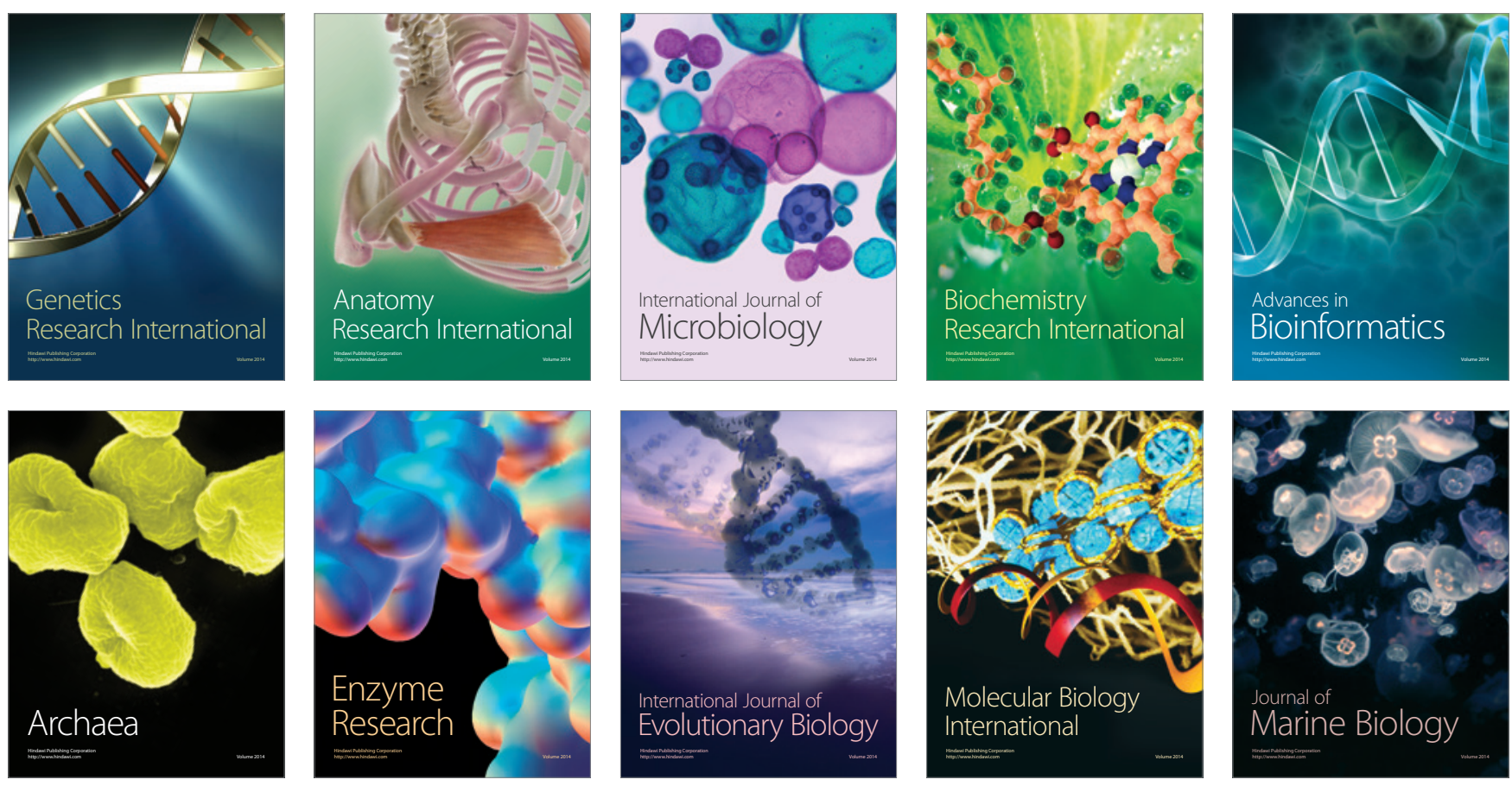